\title{
THE SEISMICITY MIGRATION STUDY BASED ON SPACE-TIME DIAGRAMS
}

\author{
E. A. Levina, V. V. Ruzhich \\ Institute of the Earth's Crust, Siberian Branch of RAS, Irkutsk, Russia
}

\begin{abstract}
Seismicity migration is studied by a new method based on space-time diagrams and a combination of cluster and regression analyses. Data from the global and Baikal regional earthquake catalogues are analysed with the application of the specially designed geographic information system (GIS) in order to establish parameters and mechanisms of seismicity migration in space and time. We study the migration of seismic events in the following geostructural systems: the Baikal rift zone (BRZ), the area between BRZ and the Indo-Eurasian interplate collision zone, the area between BRZ and the West-Pacific seismic foci Benoiff zone, and two segments of the Middle Atlantic ridge.

As evidenced by the obtained results, studying regimes of seismic migration provides for analyses of space-time distribution of seismic energy in the fault-block structure of the lithosphere and facilitates more detailed studies of the origin of deformation waves and mechanisms of the seismotectonic regime of the Earth. Forward (from the equator) and backward (towards the equator) migration of seismic events are established in all the regions under study. It is assumed that this phenomenon may result from regular changes of the polar compression of the Earth due to variations of its rotation regime. Besides, it is revealed that energy clusters of migration are regularly generated, and the regularity may be related to the 11-year cycle of the solar activity which impacts the seismic regime. We discuss the need to study the interference of wave deformations in the lithosphere which are initiated by several external energy sources. It is proposed to consider the regimes of planetary seismicity migration as a reflection of redistribution of endogenic (primarily heat) energy of the Earth during the destruction of its lithospheric shell under the impacts of cosmogenic factors via triggering mechansms. With reference to our positive experiences of applying the proposed concept to BRZ, we consider possibilities of using the seismicity migration data for prediction of earthquakes in the planetary and regional scales.
\end{abstract}

Key words: seismicity migration, space-time diagrams, cosmogenic factors, deformation waves, interference of wave deformations, prediction of earthquakes.

\section{ИЗУЧЕНИЕ МИГРАЦИЙ СЕЙСМИЧЕСКОЙ АКТИВНОСТИ С ПОМОЩЬЮ ПОСТРОЕНИЯ ПРОСТРАНСТВЕННО-ВРЕМЕННЫХ ДИАГРАММ}

\section{Е. А. Левина, В. В. Ружич}

\section{Институт земной коры СО РАН, Иркутск, Россия}

\begin{abstract}
Аннотация: Изучение процессов сейсмомиграции проводилось новым методом построения пространственно-временных диаграмм и посредством сочетания кластерного и регрессионного анализа. С помощью разработанной геоинформационной системы (ГИС) и с использованием всемирного и байкальского регионального каталогов землетрясений решались задачи по выяснению параметров и механизмов пространственно-временной миграции сейсмической активности. Сейсмомиграционные явления изучались в следующих гео-
\end{abstract}


структурных системах: в пределах Байкальской рифтовой зоны (БРЗ), между БРЗ и областью Индо-Евразийской межплитной коллизии, между БРЗ и Западно-Тихоокеанской сейсмофокальной зоной Беньофа, а также в двух сегментах Срединно-Атлантического хребта.

На основе анализа полученных результатов показано, что изучение режимов сейсмомиграций позволяет анализировать пространственно-временное перераспределение сейсмической энергии в разломно-блоковой структуре литосферы и, соответственно, более углубленно изучать деформационно-волновую природу и механизмы формирования сейсмотектонического режима Земли. Установлено проявление прямых (от экватора) и обратных (к экватору) сейсмомиграций для всех рассмотренных районов. Предполагается, что такое явление может быть объяснено периодическим изменением полярного сжатия Земли за счет вариаций ее ротационного режима. Выявлена также периодичность в режиме генерации энергетических кластеров миграции, что может быть связано с влиянием на сейсмический режим 11-летнего цикла солнечной активности. Обсуждается необходимость изучения интерференции волновых деформаций в литосфере, возбужденных несколькими внешними энергетическими источниками. С этих позиций режимы планетарной сейсмомиграции предлагается рассматривать как отражение перераспределения эндогенной, преимущественно тепловой, энергии нашей планеты в ходе деструкции ее литосферной оболочки под воздействием космогенных факторов через триггерные механизмы. На основе положительного опыта для БРЗ обсуждаются возможности применения полученных сведений о сейсмомиграции для прогноза землетрясений в планетарном и региональном масштабе.

Ключевые слова: сейсмомиграция, пространственно-временные диаграммы, космогенные факторы, деформационные волны, интерференция волновых деформаций, прогноз землетрясений.

\section{INTRODUCTION}

Earthquake migration, that was first recognized in the middle of the 20th century, has been revealed in all the seismic belts of the Earth [Mogi, 1968; Ruzhich et al., 1989; Ruzhich, Levina, 2012; Vikulin et al., 2000; Chery et al., 2001; Bykov, 2005; Liu et al., 2010; Levina, Ruzhich, 2010; Levina, 2011; Vikulin et al., 2012; Sherman, 2013, 2014; Novopashina, 2013; Novopashnina, San'kov, 2015; Dolgaya, Vikulin, 2015]. The term of 'earthquake migration', however, has not been unanimously accepted due to the fact that earthquake foci and epicentres do not actually migrate but occur in the inter-block medium and are manifested in implicit patterns and trends in space and time. In some publications, parameters of seismic migration were estimated from data on rare separate epicentres of strong earthquakes, while the analysed data ranges were small and not representative statistically. Some studies were focused on sequences of the occurrence of earthquake epicentres along fault zones of various scales, including interplate ones, and considered trends in the distribution of earthquake epicentres in the lithosphere blocks in space and time. In our opinion, among the synonyms, the term of 'seismicity migration' seems preferable for describing space-time patterns and statistically significant trends in the distribution of seismic events that occur between the hierarchically regular blocks of the lithosphere.

The phenomenon of 'seismicity migration' is typically characterized by two parameters, direction and velocity. In our previous publications [Levina, Ruzhich, 2010; Levina, 2011; Ruzhich, Levina, 2012], it was shown that estimations of the velocity of earthquake foci migration can differ significantly depending on grouping of seismic events by their energy levels. Moreover, due to the lack of a uniform approach to studies of seismic migration, an adequate comparison of published regional data and estimations is impossible, and geodynamic conditions causing the seismicity migration phenomena during the destruction of the lithosphere cannot be reliably clarified.

Since 2009, we have been developing our method that refers to total amounts of seismic energy released by earthquakes, instead of data on separate earthquake epicentres of various energy levels. A total amount of released seismic energy is calculated for a selected area in appropriate space and time windows [Levina, Ruzhich, 2010; Levina, 2011; Ruzhich, Levina, 2012]. Our approach is sufficiently formalized and can be applied to studies and analyses of seismicity of the entire Earth or separate regions, pending the availability of earthquake catalogues containing records of coordinates, time and energy of each seismic event.

\section{DESCRIPTION OF THE METHOD}

In order to study seismicity migration within the Baikal rift zone (BRZ) and the Baikal-Himalayan region, we use data from the BRZ Earthquake Catalogue published by the Baikal Branch of the Geophysical Centre, Siberian Branch of RAS (Irkutsk, Russia). The catalogue contains records from 1963 to 2014. We also use data on earthquakes $(\mathrm{M} \geq 3.5)$ from the world catalogue published by the Northern California Earthquake Data Center (USA) [Northern California Earthquake..., 2015].

In order to study the seismic process, we analyse 
coordinates, time and energy levels of seismic events and actually deal with the following equation containing three variables:

$$
E=f(\varphi, \lambda, t),
$$

where $\mathrm{E}$ is seismic energy, $\varphi$ is latitude, $\lambda$ is longitude, and $t$ is time. It is a complicated task to visualise and study the function of the three variables as its diagram needs to be a 4D curve; therefore, we apply the dimension reduction method [Popov, 2013] as described below. For the region under study, a belt-shaped area is selected with specified coordinates of datum points and a specified width. The band is split into rectangular segments which sides are perpendicular to the central line. The length of such a segment is equal to that of the specified spatial window (Fig. 1). For each segment, we estimate total amounts of the seismic energy released within specified time windows. The space-time matrix is established, and the above-mentioned function is transformed as follows:

$$
E=f(r, t) \text {, }
$$

where $r$ is distance from the datum point at the central line of the selected band. This exercise provides for presenting the two spatial coordinates, $\varphi$ and $\lambda$ by one value, $r$. It becomes possible to make a function containing two variables and construct its 3D surface. For further analyses, a cross-section of the studied surface by plane $K=K s$ and its projection to the space-time plane are constructed (Fig. 2). Values of Ks are selected with regard to specific features of the seismic regime of the region under study and aims of the study. In further data processing, differences in energy classes of individual cells are not taken into account, while each cell is considered as a point on the space-time plane. As a result, the function is transformed as follows:

$$
\mathrm{T}=\mathrm{f}(\mathrm{r})
$$

where $\mathrm{T}$ is time, and $\mathrm{r}$ is distance from the estimation start point.

To clarify a method for analyses of the obtained diagrams, we compile a test catalogue of 12 restraint events. Maps and diagrams constructed on the basis of the test catalogue are given in Fig. 3. Two tests use data on the same events but in different sequences. In the first test (left top map), restraint events 'migrate', i.e. propagate in time in the following sequence: from SW to NE (red dots), then backward, to SW (green dots), and again to NE (purple dots). The corresponding diagram is shown next to the map. In the second test (right bottom map), the events migrate from NE to SW (purple dots) and then backward, to NE (green dots) and again to SW (red dots). The corresponding diagram is shown next to the map. The diagrams show that the migration of the events in time along the specified line correspond to diagonal chains of dots in the diagrams. It is noted that if the events migrate away from the datum point, the chains are inclined to the right, and if the events migrate toward the datum point, the chains are inclined to the left. The inclination to the left, which is often recorded in the latter case, means the backward seismicity migration. This phenomenon is demonstrated in BRZ (Fig. 2). Generally, researchers pay little or no attention to the backward seismicity migration.

For further studies of the obtained diagrams, we combine methods of cluster and regression analyses. The cluster analysis deals with sets (n) of objects, and each of such objects is characterized by measurements (k). Clustering is the task of grouping a set of objects in such a way that objects in the same group (called a 'cluster') are more similar (in some sense or another) to each other than to those in other groups (clusters) [Zagoruiko, 1999]. In the past 10-15 years, thanks to the development of IT technologies, cluster analysis was widely used to address the need to process larger and larger data sets.

Typically, input data are presented as clustering algorithms. We use a modification of the non-hierarchic clustering method that is often called 'k-mean values method' [StatSoft..., 2015]. In our study, clusters are identified by grouping elements of the diagram around diagonal chains of the elements which are visually identified, and then specific elements are added into one cluster or another with respect to their proximity to the initial chain. The proximity is defined as a Euclidean distance from the given point to the straight line constructed across the initial chain and calculated from the equation. Values of distances, which determine whether the point is a member of a specified cluster, are fixed for each diagram with regard to the study aims and actual ranges of values. The difference between this method and the conventional k-mean method is that as the centre of the cluster is considered to be the line, instead of the point. By applying the algorithm, three clusters are identified in the diagram (Fig. 4). A linear regression is constructed for the set of points in the given cluster: $Y=a X+b$, where $X$ is distance $(\mathrm{km}), Y$ is time (year), and a and $\mathrm{b}$ are coefficients.

\section{RESULTS}

The regression analysis results for BRZ are shown in Table 1.

The first column of the table gives a list of clusters (from the earliest one) identified in the diagram. The second and third columns show coefficients of the 


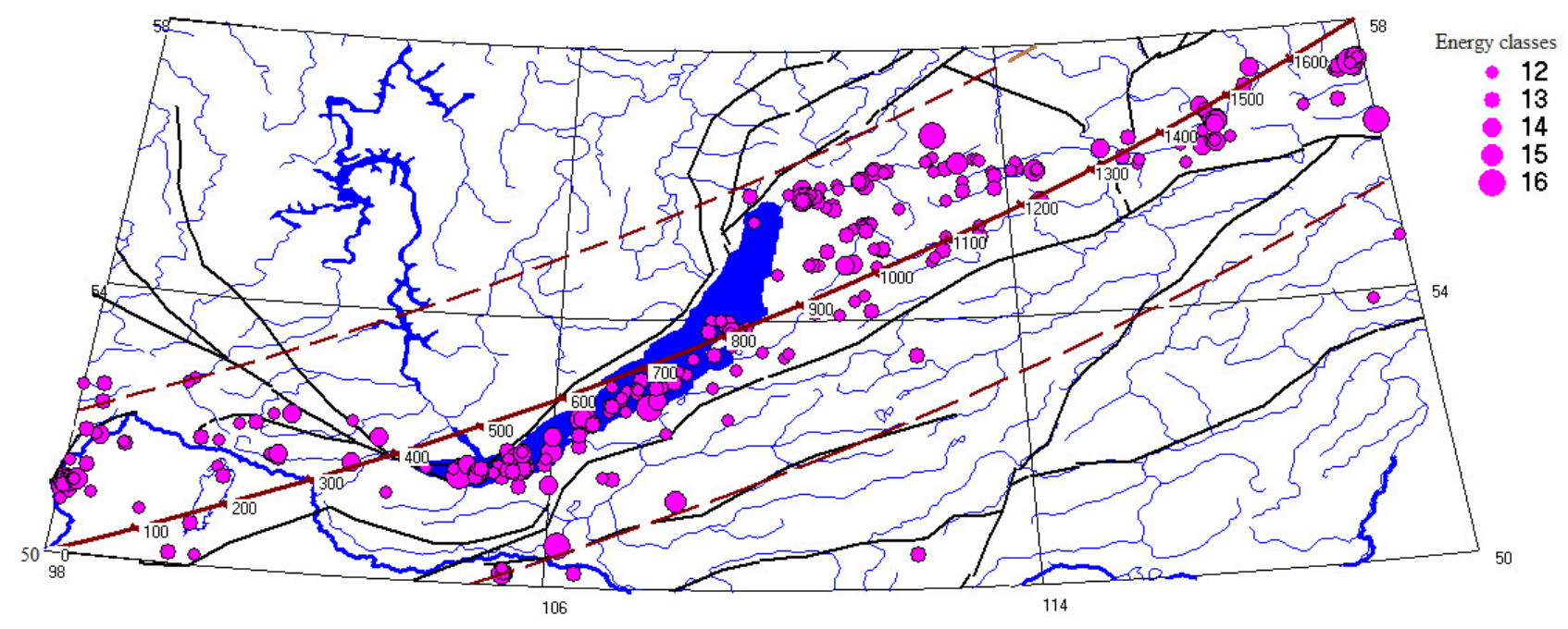

Fig. 1. In the map, the solid graduated line shows the central line of the zone under study; distances are shown in kilometres from the datum point; dotted lines show boundaries of the studied epicentral field. To consolidate the earthquake data for the period from 1963 to 2005 ( $K=12-17)$, the BRZ territory was divided into rows of rectangles, and the total energy amount released by the earthquakes was calculated.

Рис. 1. На карте сплошной линией показана центральная ось рассматриваемой зоны с нанесенными на нее делениями и указанием расстояния в километрах при удалении от начальной точки, пунктиром отмечены границы изучаемого эпицентрального поля. Данные о землетрясениях в БРЗ за период 1963-2005 гг. (К=12-17) собирались путем разделения территории на ряды прямоугольников и подсчета выделившейся суммарной энергии землетрясений.

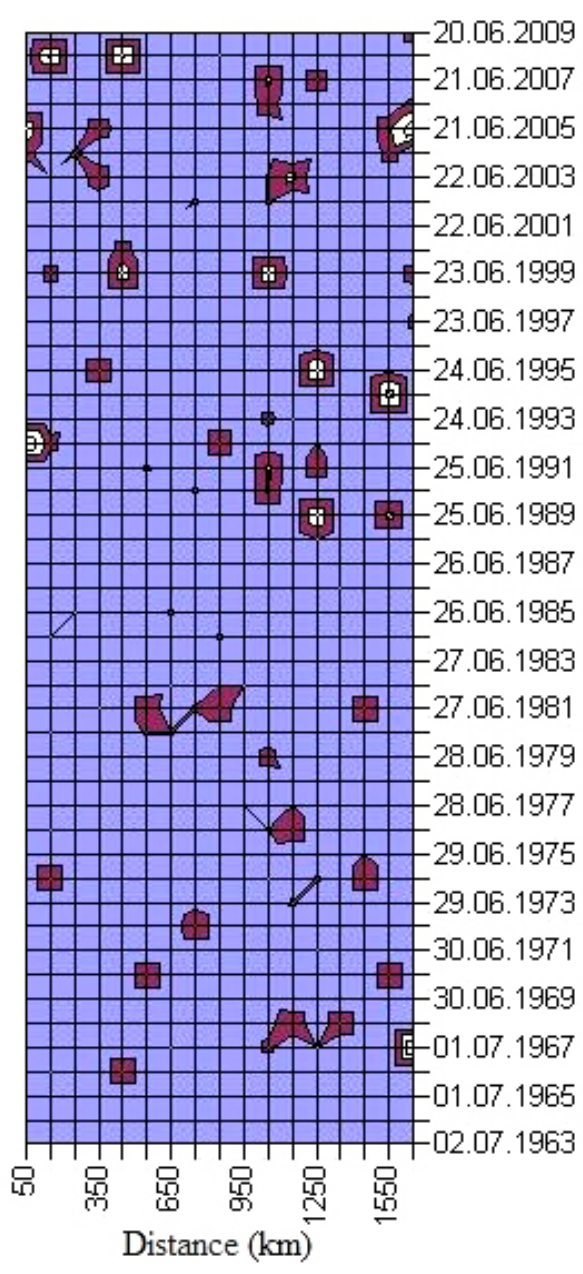

\section{Energy classes}

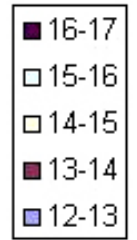

Time
Fig. 2. Space-time diagram for seismic events $(K>8)$ in the entire BRZ. The general blue background of the diagram is a cutting plane $(\mathrm{K}=12)$; other colours show maximums of seismic energy in excess of this value.

Рис. 2. Пространственно-временная диаграмма событий с К>8 для всей БРЗ. Общий синий фон диаграммы это секущая плоскость (К=12), другими цветами показаны максимумы сейсмической энергии, превышающие это значение. 


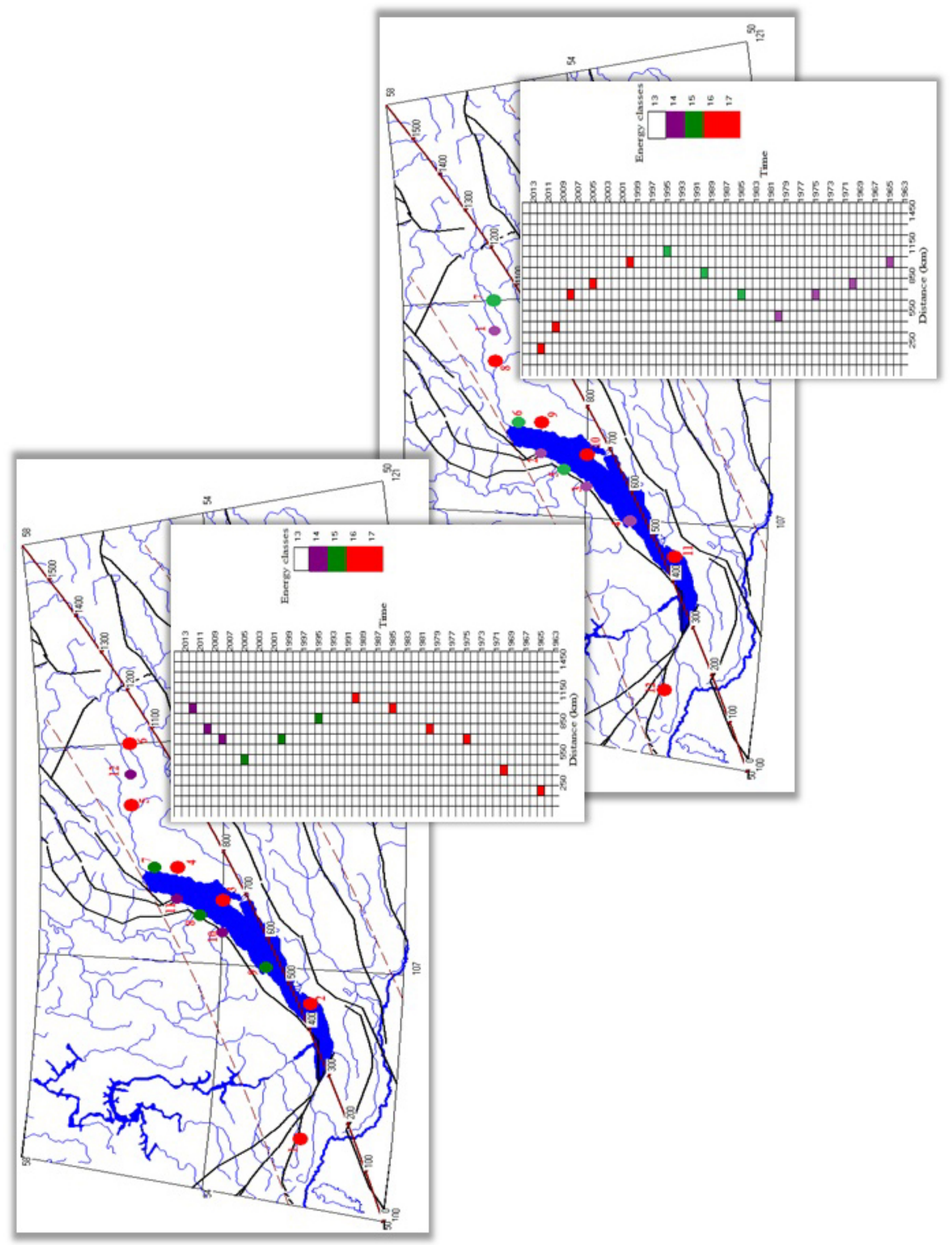




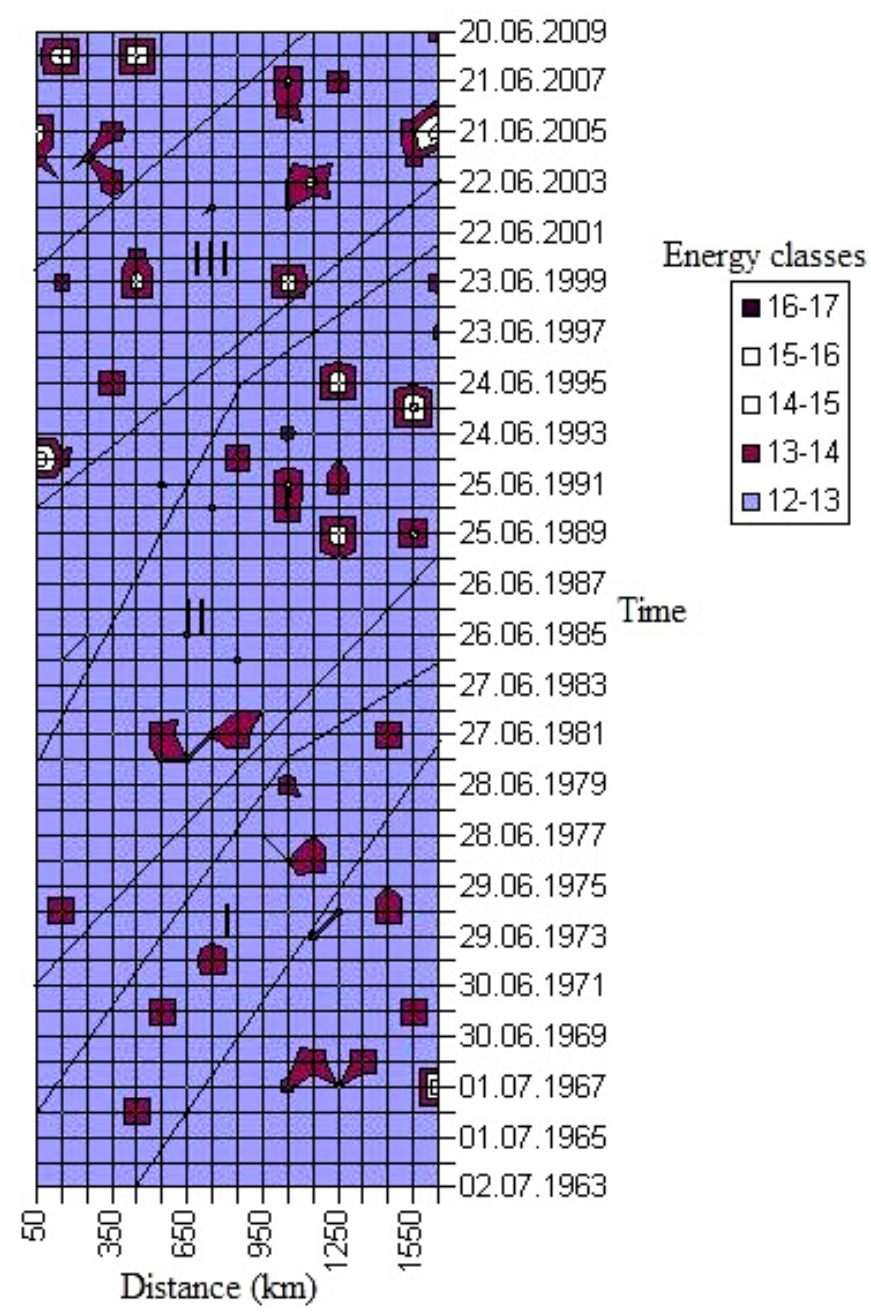

regression equation. The fourth and fifth columns show the correlation coefficient and its errors. The sixth column shows migration velocities for the given cluster according to the following equation:

$$
V=\frac{1}{a^{\prime}}
$$

where $\mathrm{V}$ is velocity, and $a$ is coefficient of the regression equation.

The seventh, eighth and ninth columns show start time, finish time and duration of each cluster, which
Fig. 4. Space-time clustering of events $(K \geq 8)$. Clusters are revealed by grouping elements of the diagram in areas stretching from SW to NE, which reoccur regularly with time.

Рис. 4. Выделение пространственно-временных кластеров для событий с К $\geq 8$. Критерием для выделения кластеров служила группировка элементов диаграммы в областях, простирающихся с юго-запада на северо-восток и повторяющихся с некоторой временной периодичностью. are calculated from the repression equation. The space-time diagram and assumed migration lines are shown in Fig. 5.

The above-described calculation method is also applied to studying seismicity migration in other territories. The map showing boundaries of the regions under study is given in Fig. 6. Studied regions: 1. BRZ; (2) Himalayas - BRZ; (3) Japan - BRZ; (4) Northern Atlantic Ocean; (5) Southern Atlantic Ocean.

Seismicity migration in the Pamir-Baikal segment, including the territory from the Himalayan collision area to BRZ, is studied for the period from 1963 to

$\mathrm{T}$ a b l e 1. Parameters of three clusters identified for BRZ

Т а б л и ц а 1. Параметры трех выделенных кластеров для БР3

\begin{tabular}{|c|c|c|c|c|c|c|c|c|}
\hline Cluster & $\mathrm{a}$ & $\mathrm{b}$ & r & $\mathrm{sr}$ & V & $\begin{array}{l}\text { Started in } \\
\text { (year) }\end{array}$ & $\begin{array}{l}\text { Finished in } \\
\text { (year) }\end{array}$ & $\begin{array}{l}\text { Duration } \\
\text { (years) }\end{array}$ \\
\hline 1 & 2 & 3 & 4 & 5 & 6 & 7 & 8 & 9 \\
\hline 1 - bottom & 0.0141 & 1961.27 & 0.95 & 0.041 & 70.92 & 1961 & 1985 & 24 \\
\hline 2 - medium & 0.0121 & 1976.15 & 0.77 & 0.11 & 82.64 & 1976 & 1996 & 30 \\
\hline 3 - top & 0.0086 & 1993.87 & 0.85 & 0.09 & 116.28 & 1994 & 2008 & 14 \\
\hline
\end{tabular}




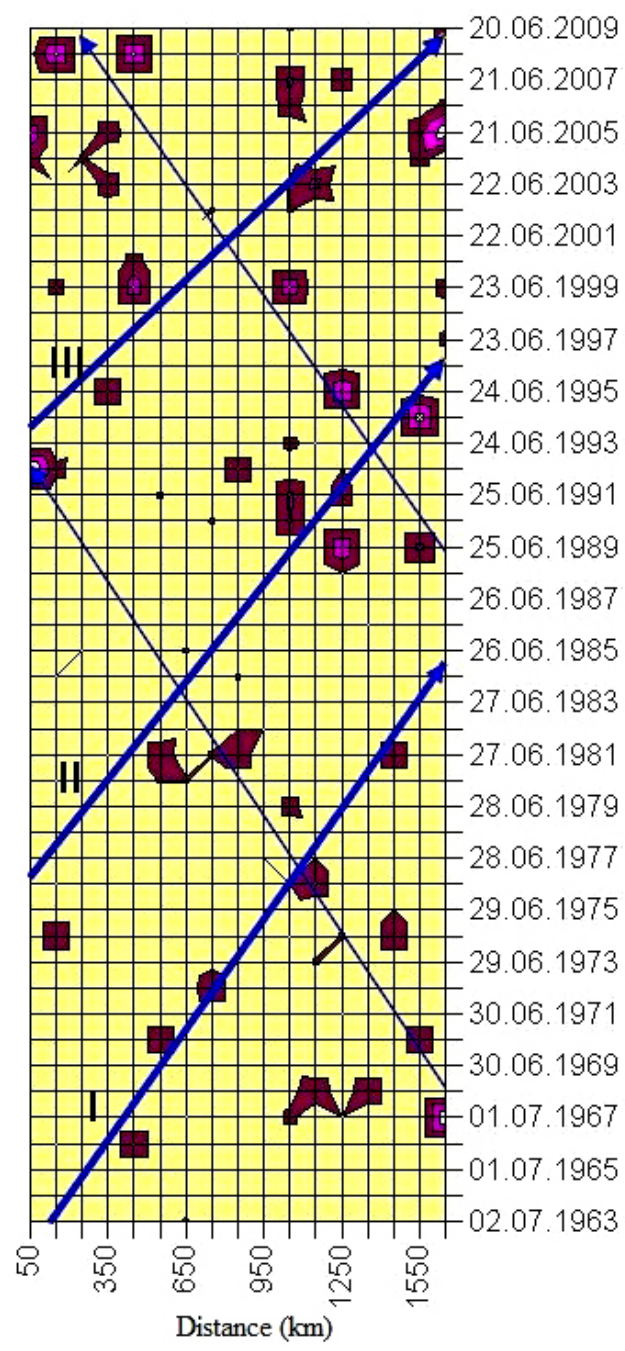

\section{Energy classes \\ -16-17 \\ $\square$ 15-16 \\ ㅁ14-15 \\ - 13-14 \\ $\square 12-13$}

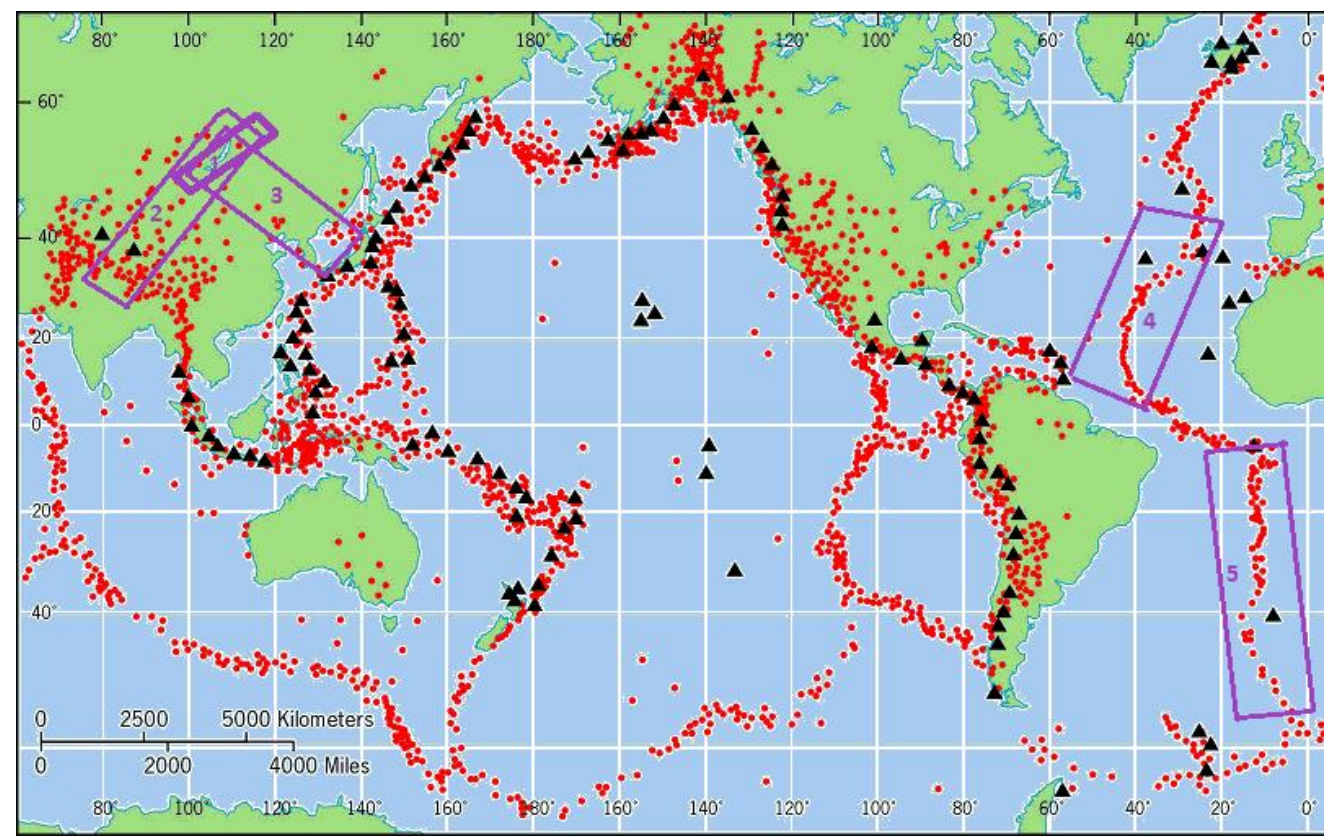

Fig. 6. Map showing boundaries of studied regions of seismicity migration. Red dots show earthquake epicentres; black triangles show volcanoes.

Рис. 6. Карта с нанесенными на нее границами рассмотренных районов миграции сейсмической активности. Красными точками отмечены эпицентры землетрясений, черными треугольниками - вулканы. 


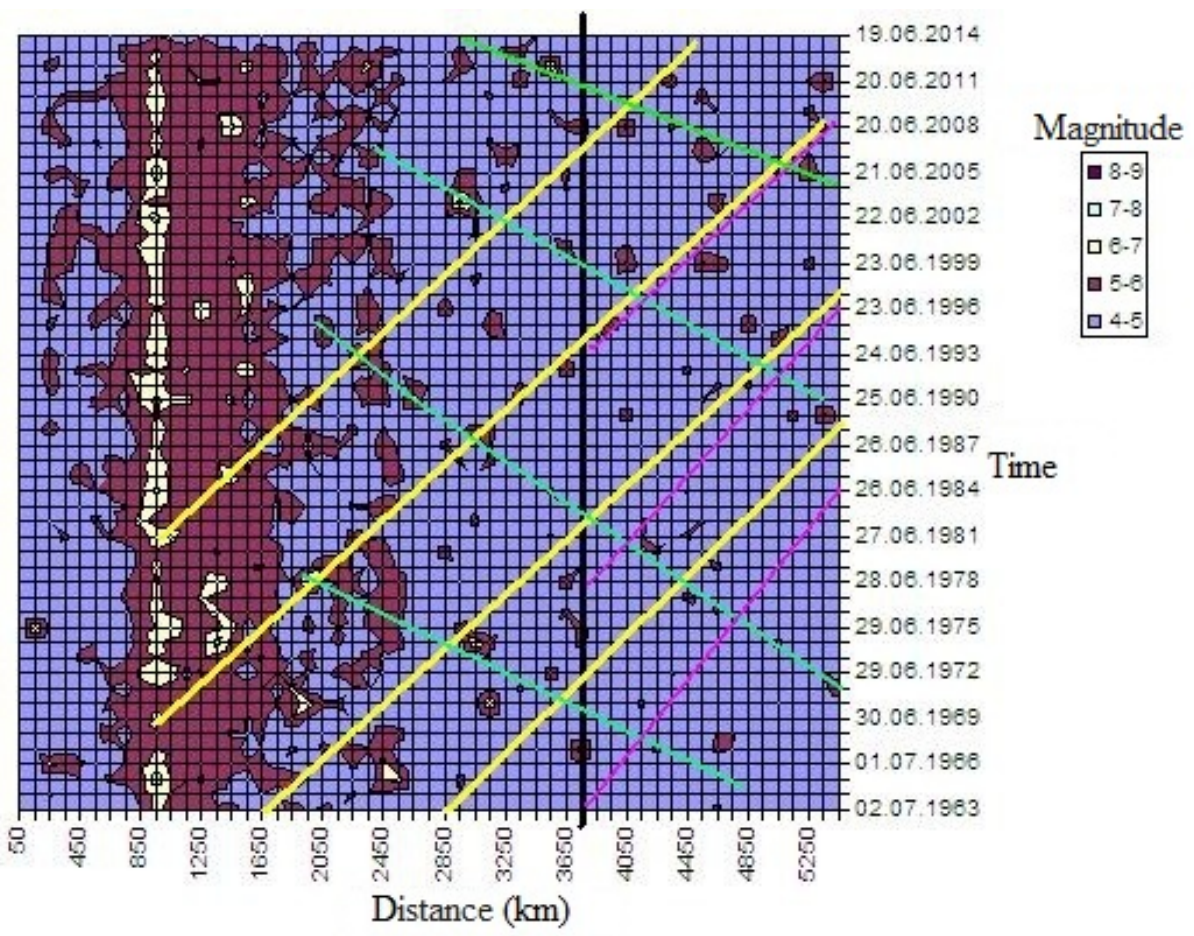

Fig. 7. Diagram of seismic activity propagation from the collision region to NE, towards BRZ in the period from 1963 to 2014 $(M \geq 4.5)$. Thick yellow lines show assumed lines of migration from SW to NE; thin green lines show backward migration. In the digram, the BRZ area is located to the right of the black vertical line. Migration lines for BRZ from diagram 8 are shown in pink.

Рис. 7. Диаграмма распространения сейсмической активности от коллизионной области на северо-восток, в сторо-

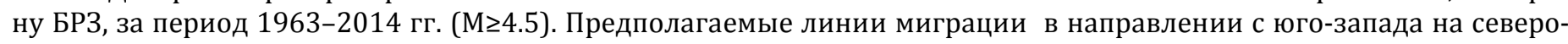
восток показаны толстыми желтыми линиями, в обратном направлении - тонкими зелеными линиями. Справа от вертикальной черной линии на диаграмме располагается область БРЗ. Линии миграции для нее с диаграммы 8 показаны розовым цветом.

2014 (events $M \geq 4$ ). The dynamics of the seismic events within the specified area in space and time is shown in the diagram (Fig. 7).

According to the digram, the seismic regime of the Pamir-Tien Shan segment ( $\mathrm{P}$ average direct $=11$ years $)$ is quasi-cyclic, and earthquake foci tend to migrate as deformation fronts from SW to NE with velocities of about $90 \mathrm{~km} /$ year. It is also noted that the migration is intermittently progressive and thus reflects the impulse regime of the propagation of the deformation fronts.

Based on our studies of the regularities in seismicity migration within the specified area, it can be concluded that the observed occurrence of seismicity migration waves can be explained by the quasi-periodic propagation of the deformation fronts in the crust from SW to $\mathrm{NE}$, i.e. from the side of the Indo-Eurasian collision area [Levina, 2011; Ruzhich, Levina, 2012]. In this respect, the rotation model of the block geomedium, which is proposed by A.V. Vikulin and A.G. Ivanchin [Vikulin, Ivanchin, 2015], is of interest. In terms of geomechanics, it assumes that rotation movements of the Earth are related with the occurrence of wave deformation and the generation of earthquakes.

In the transgression stage, movement of the deformation wave fronts to NE and actions of triggering mechanisms are accompanied by the activation of potential earthquake sources varying in ranks; such sources are located on sites characterized by the extremely high dynamic instability. Therefore, the seismicity migration mechanism of the initiation of seismic activity and directional trends of migration processes within BRZ (being a linear zone of the developing megafault) are a reflection of the kinematics of the recent deformation and destruction of the lithosphere under the influence of the external energy sources. This point of view of the authors does not contradict with concepts developed by other researchers [Vikulin, 2003; Sherman, 2013, 2014].

Another region under study is the territory from the Japan islands to BRZ. The space-time diagram is given in Fig. 8. The belt-shaped area selected for studying the seismicity migration in this region is oriented from SE to NW. Since the proposed method can be applied to 


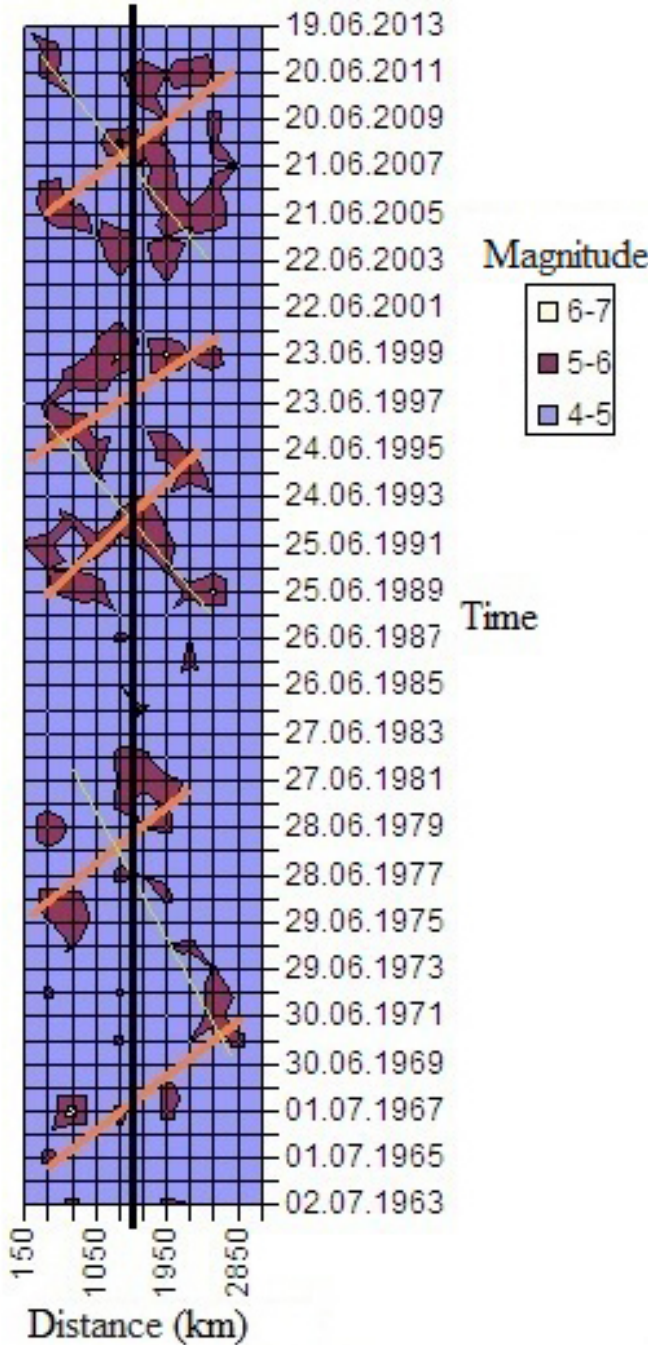

Fig. 8. Diagram of seismic activity propagation from the Benioff zone to NE, towards BRZ in the period from 1963 to $2013(M \geq 4.5)$. Thick orange lines show assumed lines of migration from SE to NW; thin green lines show backward migration. In the diagram, the BRZ area is located to the right of the black vertical line.

Рис. 8. Диаграмма распространения сейсмической активности от зоны Беньофа на северо-запад в сторону

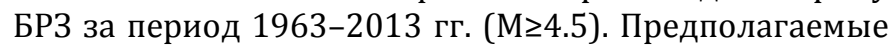
линии миграции в направлении с юго-востока на северо-запад показаны толстыми оранжевыми линиями, в обратном направлении - тонкими зелеными линиями. Справа от вертикальной черной линии на диаграмме располагается область БРЗ.

areas of various orientations, an obvious question is how to compare directional trends of earthquake foci migration in different regions. In this study, migration from the equator (in the northern hemisphere) is termed as 'forward', and migration to the equator is called 'backward'.

Windows of $300 \mathrm{~km}$ (space) and one year (time) are used to construct the diagram (Fig. 8). Five clusters of forward migration are identified. An average forward velocity amounts to $365 \mathrm{~km} /$ year, and an average forward interval between the tracks is 11 years. For backward tracks, an average backward velocity amounts to $233 \mathrm{~km} /$ year, and an average backward interval between the tracks is 16 years. Special attention should be given to results obtained in the study of seismicity migration in the southern and northern segments of the Atlantic mid-oceanic ridge (being an interplate boundary zone). Two space-time diagrams shown in Fig. 9 are constructed with windows of 300 $\mathrm{km}$ (space) and one year (time). For forward tracks in the Northern Atlantic Ocean, an average forward velocity amounts to $335 \mathrm{~km} /$ year, and an average forward interval between the tracks is 8 years. For backward tracks, an average backward velocity amounts to 225 $\mathrm{km} /$ year, and an average backward interval between the tracks is 9 years. For the Southern Atlantic Ocean, an average forward velocity amounts to $411 \mathrm{~km} / \mathrm{year}$, and an average forward interval between the tracks is 10 years; an average backward velocity amounts to $437 \mathrm{~km} /$ year, and an average backward interval between the tracks is 10 years. It is noteworthy that the starting points of the seismicity migration tracks from the equator towards the poles are close in time in both parts of the Atlantic Ocean.

Table 2 contains parameters of seismicity migration for all the regions of the world in our study.

\section{DISCUSSION OF RESULTS}

The data obtained by the proposed method are briefly reviewed and interpreted below. In Fig. 10, there are two diagrams for BRZ with the time difference of four years. In the right digram, the horizontal pink line separates a part of the digram with the end of the earlier left digram. It can be observed that some of the dots, that are not included in any clusters in the left digram, are included in the new developing cluster in the right (newer) diagram. The top yellow line at the right shows an assumed migration line in it. Comparing these two diagrams illustrates seismic prediction capacities of the proposed method that is similar to the method described in [Sherman, 2013]. According to the figure, in 2014 and 2015 , the most clearly manifested maximums of seismic activity migrated to the NE flank of BRZ.

It is reasonable therefore to assume that earthquake migration along the fault zones and inside the geoblocks is currently related to the propagation of deformation waves of various amplitudes and frequencies which are capable of initiating the activation of seismicity in the lithosphere [Bykov, 2005; Vikulin et al., 2000; Levina, Ruzhich, 2010; Sherman, 2014]. It can be thus concluded that the directional trends of the 


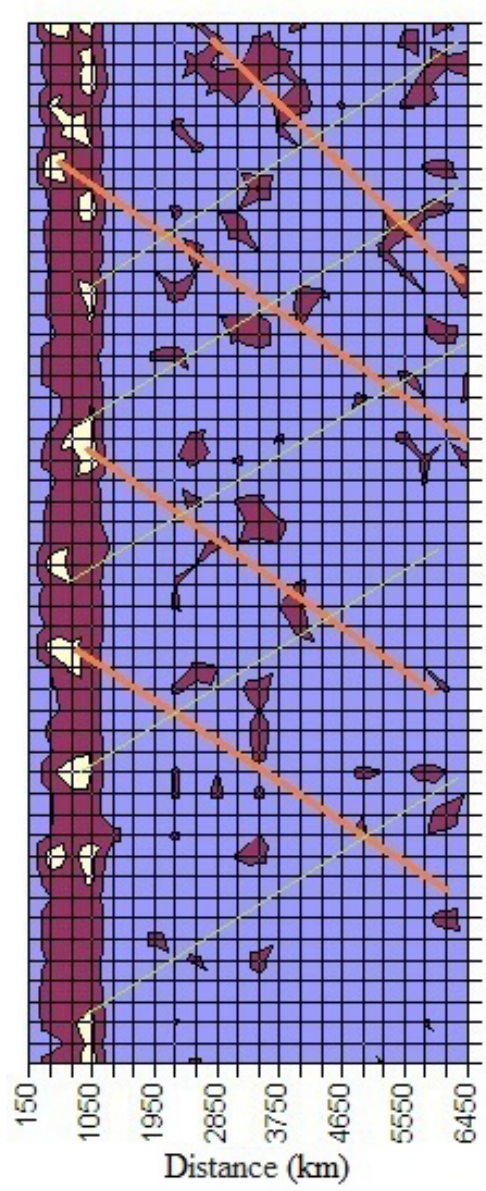

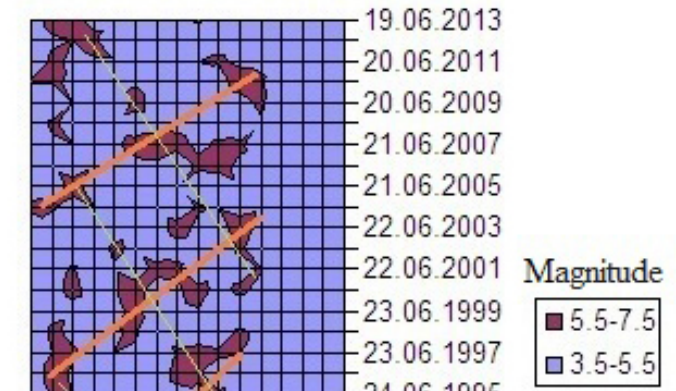

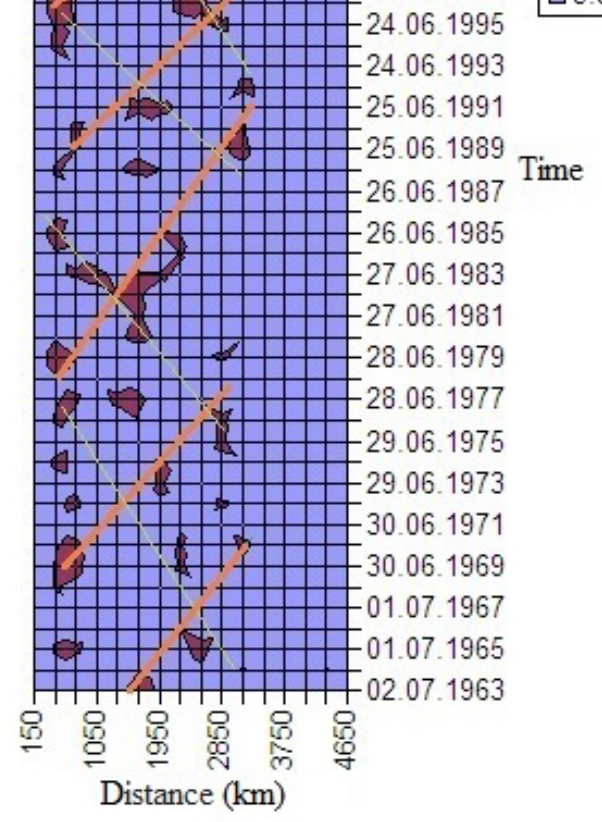

Fig. 9. Diagram of seismic activity propagation in the Southern (left) and Northern (right) Atlantic Ocean in the period from 1963 to $2013(M \geq 5)$.

Thick orange lines show assumed lines of 'forward' migration (from the equator); thin green lines show 'backward' migration (to the equator).

Рис. 9. Диаграмма распространения сейсмической активности в южной (слева) и северной (справа) части Атлантического

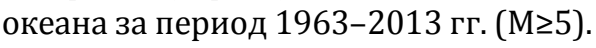

Предполагаемые линии миграции в «прямом» направлении (от экватора) показаны жирными оранжевыми линиями, в «обратном» направлении (к экватору) - тонкими зелеными линиями. migration of seismic sources can help reveal the character of deformations in the form of deformation waves or disturbance fronts.

One of the sources of wave deformation of the crust is the rotational regime of the Earth. A potential relationship between the global seismicity of the Earth and irregularities in its rotation has been a subject of intensive studies [Vikulin et al., 2000; Sidorenkov, 2004; Tyapkin, 2012]. It is known that the Earth is in an elliptical orbit around the Sun. The distance between the Earth and the Sun is changing due to the ellipticity of the orbit. According to the Kepler's second law of planetary motion, the speed of the Earth increases at peri- helion (early January) and decreases at aphelion (early July), and the speed difference amounts to almost 1 $\mathrm{km} / \mathrm{sec}$ [Odessky, 1972]. Since the total momentum of the system's motion quantity remains constant, an increase of the orbital speed of the Earth should cause a decrease of its rotation velocity, and vice versa. It is now established that the angular velocity of the Earth rotation decreases centennially due to tidal friction. In the 20th century, the day's length increased by 0.0016 sec [Odessky, 1972]. Besides, it is revealed that the angular velocity of the Earth rotation is subject to regular annual changes (minimum in April, and maximum in August) and irregular sharp fluctuations.

T a b l e 2. Parameters of seismicity migration for regions of the world

Т а б л и ц а 2. Параметры миграции сейсмической активности для различных районов мира

\begin{tabular}{llllll}
\hline Region & $\begin{array}{l}\text { Number of } \\
\text { events }\end{array}$ & $\begin{array}{l}\text { V average forward } \\
\text { (km/year) }\end{array}$ & $\begin{array}{l}\text { P average direct } \\
\text { (year) }\end{array}$ & $\begin{array}{l}\text { V average backward } \\
\text { (km/year) }\end{array}$ & $\begin{array}{l}\text { P average backward } \\
\text { (year) }\end{array}$ \\
\hline BRZ & 31305 & 90 & 14 & 62 & 16 \\
Himalayas - BRZ & 14960 & 90 & 11 & 160 & 16.5 \\
Japan - BRZ & 3107 & 365 & 11 & 233 & 16 \\
Northern Atlantic Ocean & 1901 & 335 & 8 & 9 \\
Southern Atlantic Ocean & 5339 & 411 & 10 & 437 & 9.5 \\
\hline
\end{tabular}




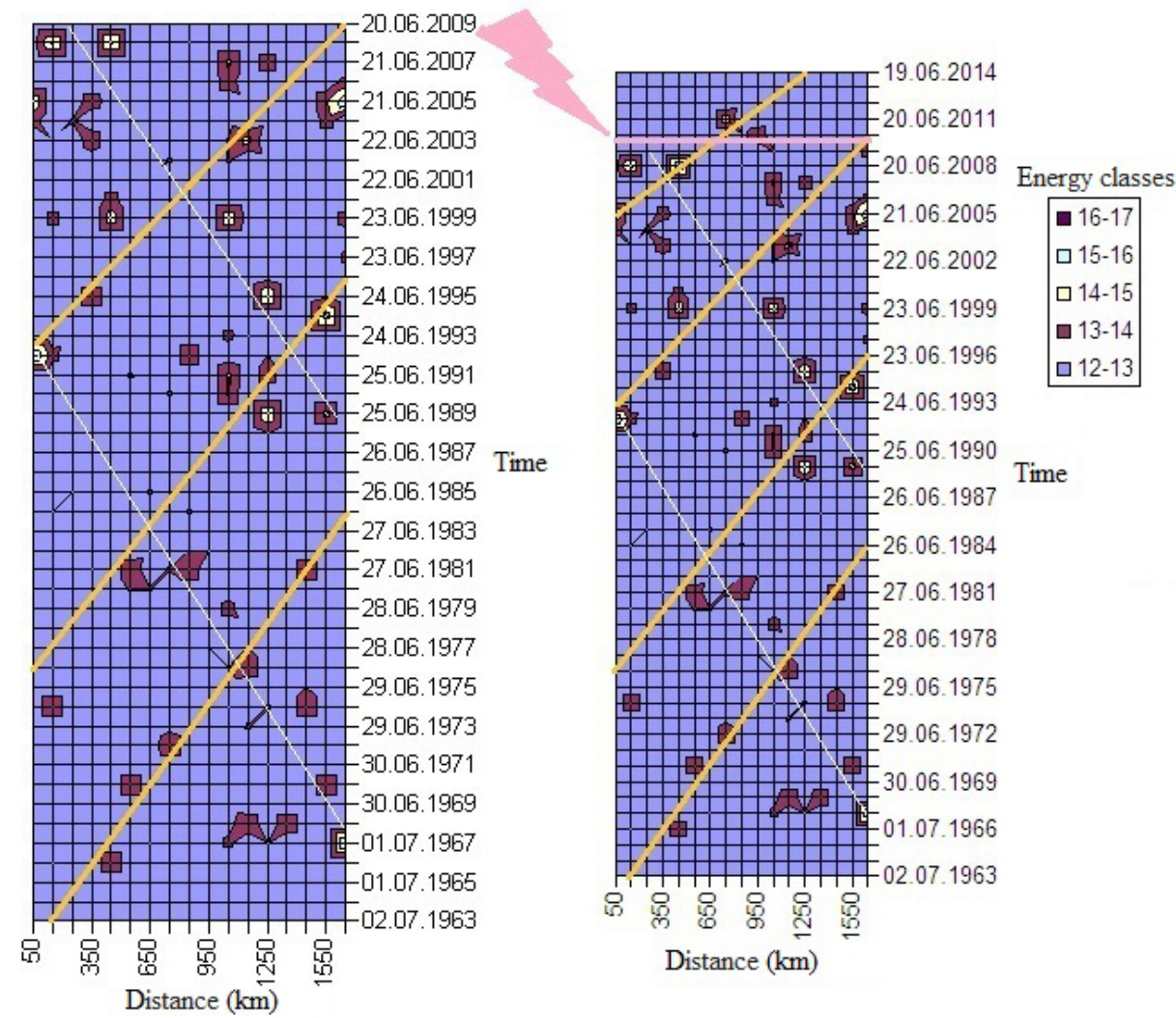

Fig. 10. The diagrams differ by four (4) years. The top yellow line at the right shows an assumed migration line in the developing cluster.

Рис. 10. Правая диаграмма построена через четыре года после левой. Верхняя желтая линия справа показывает предполагаемую линию миграции в новом формирующемся кластере.

Being in the state of hydrostatic equilibrium, the Earth reacts to a change of its angular velocity by a change of its polar compression (Fig. 11):

$$
\alpha=\frac{a-c}{a},
$$

where $\alpha$ is equatorial radius, and $c$ is polar radius of the Earth.

The Earth rotation axis is not fixed in space. Since the rotation axis is precessing due to the gravity of the Sun and Moon, the celestial pole moves in a loop around the ecliptic pole in a cycle of approximately 26000 years. Gravity forces are changeable as the Sun and Moon continuously change location relative to each other and relative to the Earth, and thus the Earth's axis is subject to nutation. The largest component of Earth's nutation has a period of 18.6 years, the same as that of the precession of the Moon's orbital nodes. The movements of the Earth axis in space are schematically shown in Fig 12. Moreover, the Earth wobbles around the rotation axis, and the current pole (while moving from west to east) follows a spiralshaped centroid curve within a $30 \times 30 \mathrm{~m}$ square area on the surface of the Earth. Concerning the pole movements, the centennial trend is revealed, and two periodic wobbles - the free (Chandler) which has a period of 14 months, and a forced wobble with a period of one year - and non-periodic wobbles are recognized.

In 1970s, some of the researchers concluded that stresses that occur in the Earth crust due to the rotation are sufficiently large to disturb the integrity of the crustal layer [Stovas, 1963; Tsaregradsky, 1963; Vikulin et al., 2000; Bykov, 2005]. Besides, it was revealed that the gravity interrelations in the Sun-Earth-Moon system are periodically changing [Vorobiev, 1971; Dovbnich, 2007; Maximov et al., 1967; Revuzhenko, 2013].

According to [Utkin et al., 2012], variations of the Earth rotation regime are always preceding an increase of the general seismicity of the Earth: the change of the sign of the Earth movement acceleration is a general (for all the earthquakes on the planet) short-term precursor of a tectonic earthquake, and all the earthquakes with $M>6$ were mandatory preceded by a sudden change of the Earth rotation acceleration. In analyses of Table 2 and the space-time diagrams (Fig. 5, and 7 to $10)$, it is noted that the migration lines are located in an enchelone pattern and reoccur with time. The regular 


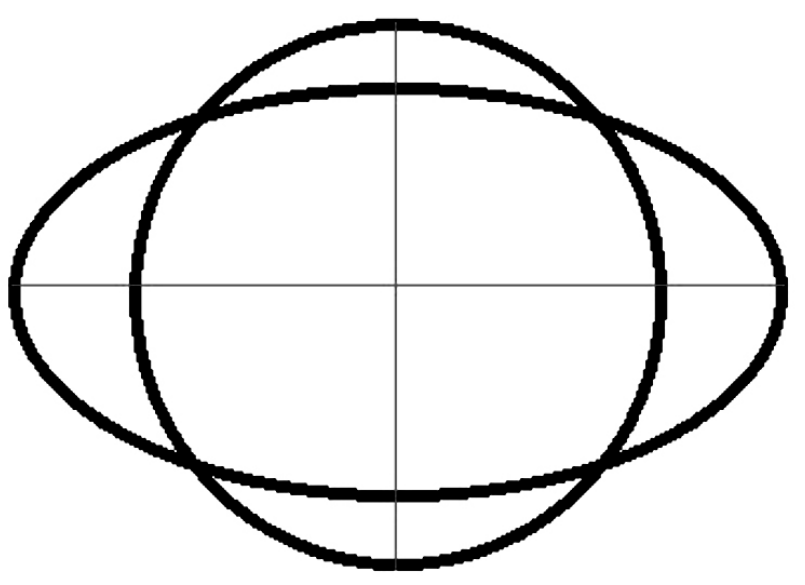

Fig. 11. Variations of the polar compression of the Earth.

Рис. 11. Схема, иллюстрирующая изменение полярного сжатия Земли.

occurrence of earthquakes in BRZ is noted by many researchers, and an 11-year cycle is related to the cycle of the solar activity [Lyubushin et al., 1998]. There are grounds to suggest that the seismicity migration along BRZ and the regular occurrence of earthquakes in BRZ may manifest the same regularities. If so, the identified cycle of the reoccurrence of the migration clusters ( $\approx 11$ years) is another confirmation of the fact that seismicity is influenced by the solar activity cycles [Sobolev et al., 1998; Shestopalov, Kharin, 2004].

In Fig. 13, the curve shows earthquake quantities in BRZ in the period from 1963 to 2013 versus changes of the Wolf (relative sunspot) number [Levi et al., 2012] in the same period; the values are averaged in the oneyear cycles. A relationship between two rows of digits can be given by the following equation: $y=0.28^{*} \mathrm{x}^{195.41}$, with correlation coefficient $\mathrm{R}=0.47 \pm 0.11$.

An interpretation of the curves can provide an additional support for the conclusion that the seismotectonic regime of the Earth is influenced by the solar activity. In this respect, noteworthy is another concept of a potential mechanism of the relationship between the Earth seismicity and the solar activity. According to [Orlov et al., 2007], the mechanical recoil momentum, that is received by the Sun in case of a strong emission during the flare, can change the gravity field and thus cause corresponding deformation disturbances in the crust of the Earth. This conclusion is based on longterm oscillation records by laser deformation meters and an assumption that the planetary orbits are stable.

In our studies of the earthquake migration in BRZ, it is noted that maximums of seismic activation can relocate in space under a complicated pattern [Levina, Ruzhich, 2010; Levina, 2011]. This assumption is well illustrated by a case of seismicity migration in the peri- od from December 2012 to January-March 2015. In this period, the Irkutsk Seismic Station registered a strong earthquake (M=7-8) at the boundary between BRZ and the Republic of Tyva and indicators of the seismicity migration from the boundary towards the NE flank of BRZ. Near Severomuisk, starting from 03 January 2015, an energy cluster continued its development. This spatially dense swarm of earthquakes is represented by a series of seismic events, including earthquakes with $\mathrm{K} \leq 13.2(\mathrm{M}=7-8)$ and numerous $(160+)$ weak and measurable shocks. In [Ruzhich, 1997], it is discussed that such a high swarm-type seismic activity occurs typically at the intersections of faults generating seismicity and may last for many months and even years.

In view of the above-mentioned periodicity, that is characteristic of the seismic regime of BRZ, the observed seismicity migration regime can be considered as a manifestation of the whole range of deformation waves with various amplitude, frequency and velocity values. Important information on parameters of deformation waves was published in [Sherman, 2013, 2014].

Taking into account a wide variety of energy sources capable of generating the wave oscillations in the lithosphere of the Earth, it becomes obvious that their interference needs to be studied, and the challenge of

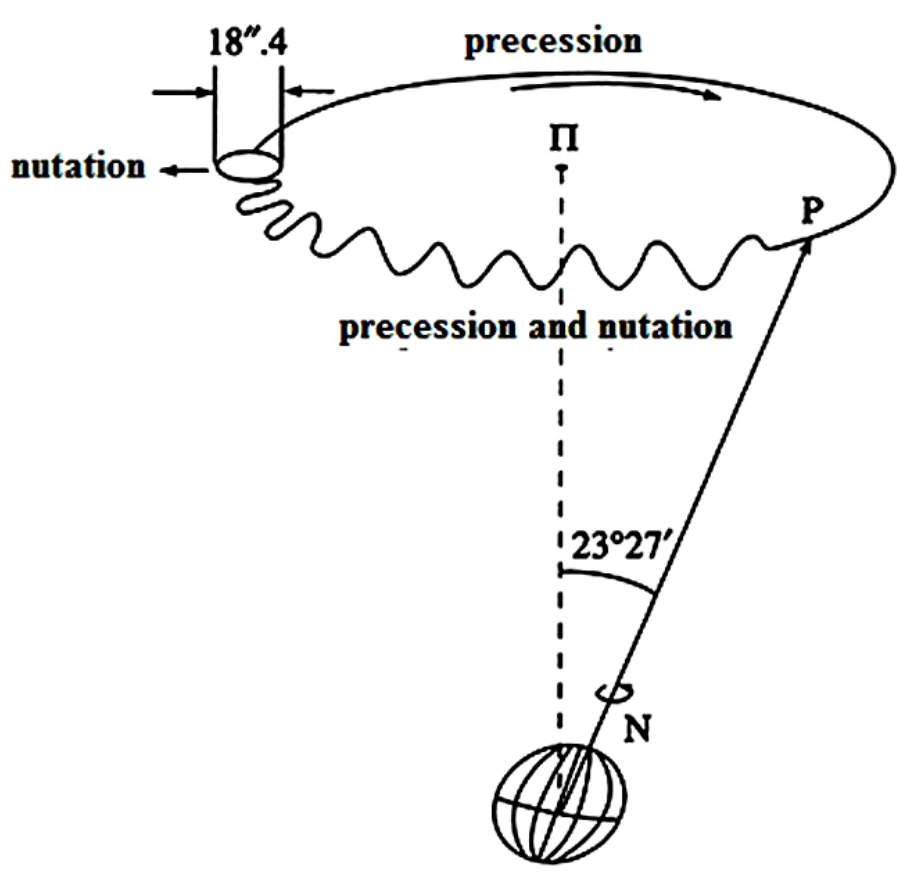

Fig. 12. The Earth's axis movement in space as viewed by an extraterrestrial observer. The scheme was published in [Sidorenkov, 2004].

Рис. 12. Схема движения оси Земли в пространстве для внеземного наблюдателя (схема из статьи [Sidorenkov, 2004]). 
Latitude: $50.0-58.0$ Longitude: $98.0-122.0$ Energy classes: $8-17$
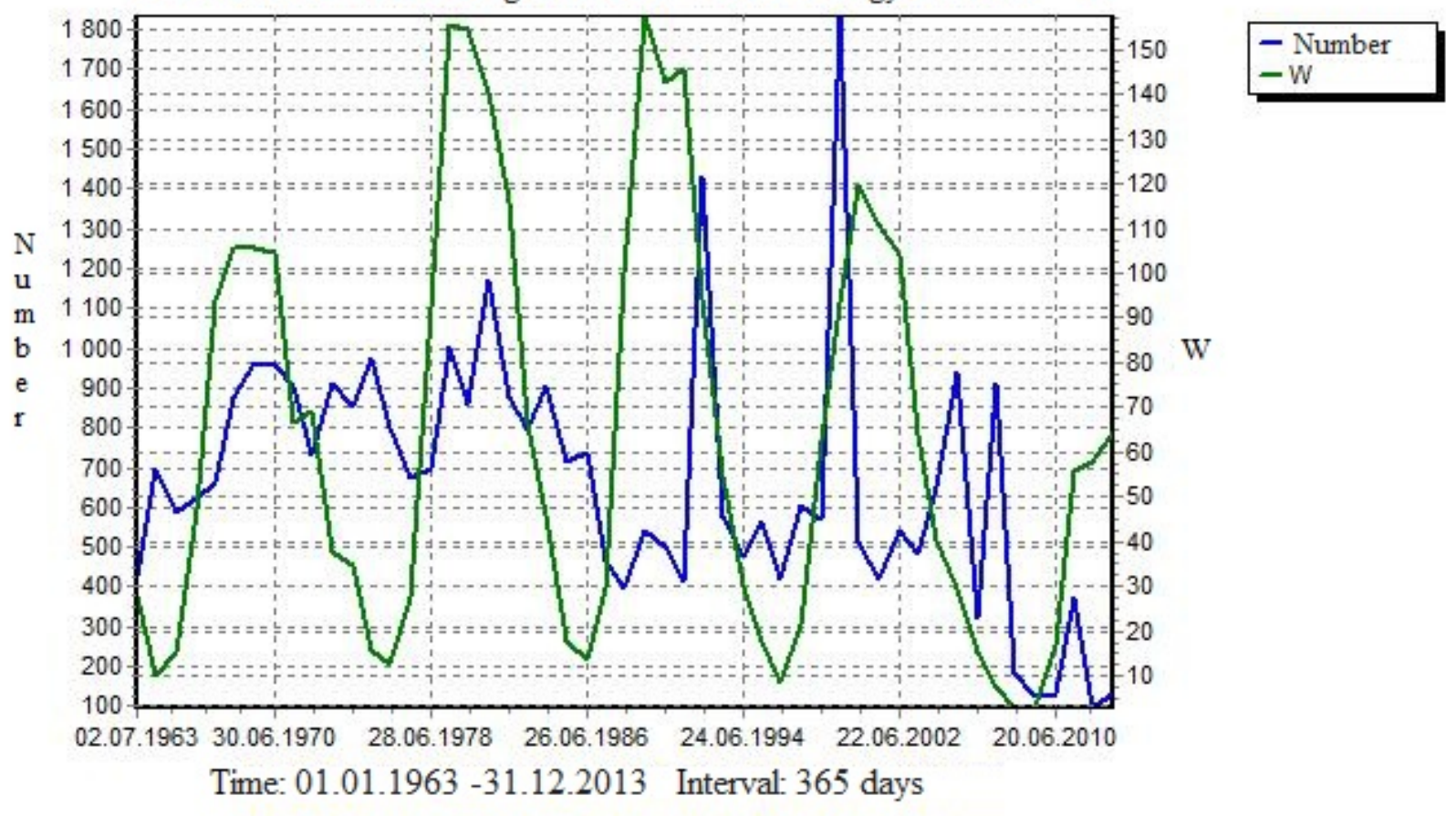

W

Fig. 13. Comparison of number-of-earthquake curves for BRZ and variations of Wolf numbers (both values are averaged in one-year intervals) for the period from 1963 to 2013.

Рис. 13. Сравнение графиков количества землетрясений в БРЗ и изменения чисел Вольфа (обе величины усреднены по интервалу времени в 1 год) за период 1963-2013 гг.

determining the wave parameters and their origin becomes even more complicated due to wave superposition and interaction.

\section{CONCLUSION}

Many researchers are interested in studies of the seismicity migration and search for possibilities to estimate and analyse its parameters in space and time with account of contact interactions in the interblock lithospheric medium at different scale levels. Our method applied to studies of seismicity migration can be viewed as an instrument for identification of causes and mechanisms of directional propagation of the seismic energy generated by recent destruction of the lithosphere of the Earth. The knowledge of seismicity migration parameters can help in distinguishing fastresponse extraterrestrial energy sources that facilitate the propagation of various deformation waves in the lithosphere of the Earth. Despite the fact that the latter do not have a significant energy, their impact is sufficient for triggering the seismic activity in tectonic zones of faults in the lithosphere, which are characterised by high stresses.

As shown by the results of our study of the seismicity migration in BRZ developing as a megafault in the Eurasian plate, the phenomenon of seismicity migration can be considered as an additional factor that can be referred to in attempts of middle-term prediction of earthquakes, as discussed in [Ponomareva et al., 2014].

\section{6. ЛИТЕРАTУРА / REFERENCES}

Bykov V.G., 2005. Deformation waves of the Earth: concept, observations and models. Geologiya i Geofizika (Russian Geology and Geophysics) 46 (11), 1176-1190.

Chery J., Merkel S., Bouissou S., 2001. A physical basis for time clustering of large earthquakes. Bulletin of the Seismological Society of America 91 (6), 1685-1693. http://dx.doi.org/10.1785/0120000298.

Dolgaya A.A., Vikulin A.A., 2015. Study of space-time regularities of seismicity in the Baikal rift zone. In: Tectonics and geodynamics of the continental and oceanic lithosphere: general and regional aspects. Proceedings of the XLVII 
Tectonic Meeting, vol. 1. GEOS, Moscow, p. 130-133 (in Russian) [Долгая А.А., Викулин А.А. Исследование пространственно-временных закономерностей сейсмичности Байкальской рифтовой зоны // Тектоника и геодинамика континентальной и океанической литосферы: общие и региональные аспекты: Материалы XLVII Тектонического совещания. М.: ГЕОС, 2015. Т. 1. С. 130-133].

Dovbnich M.M., 2007. The influence of variations of Earth's rotational mode and lunar-solar tides on a stressed state of the tectonosphere. Reports of the National Academy of Sciences of Ukraine (Dopovidi Natsionalnoi Akademii Nauk Ukrainy) (11), 105-112 (in Ukrainian) [Довбнич М.M. Влияние вариаций ротационного режима Земли и лунно-солнечных приливов на напряженное состояние тектоносферы // Доповіді Національної академії наук України. 2007. № 11. С. 105-112].

Levi K.G., Zadonina N.V., Yazev S.A., Voronin V.I., Naurzbaev M.M., Khantemirov R.M., 2012. Heliogeodynamics: Natural Aspects of Global Solar Minimums. In 3 volumes. Vol. 1, Book 1. Publishing House of the Irkutsk State University, Irkutsk, 511 p. (in Russian) [Леви К.Г., Задонина Н.В., Язев С.А., Воронин В.И., Наурзбаев М.М., Хантемиров Р.М. Гелиогеодинамика: Природные аспекты глобальных солнечных минимумов. В 3 т. Т. 1, кн. 1. Иркутск: Изд-во ИГУ, 2012. 511 с.].

Levina E.A., 2011. Geoinformation System for Prediction of Earthquakes and Rock Shocks: Development and Application for the Baikal Rift Zone and the Norilsk Field. Synopsis of the Thesis, PhD in Geology and Mineralogy. Irkutsk, 19 p. (in Russian) [Левина E.A. Геоинформационная система для прогноза землетрясений и горных ударов: разработка и примеры применения в Байкальской рифтовой зоне и Норильском месторождении: Автореф. дис. ... канд. геол.-мин. наук. Иркутск, 2011. 19 с.].

Levina E.A., Ruzhich V.V., 2010. Earthquake migration of various scales as manifestation of the initiated energy flow in case of wave deformations of the lithosphere of the Earth. In: Triggering mechanisms in geosystems: proceedings of the All-Russia Workshop-Meeting. GEOS, Moscow, p. 71-78 (in Russian) [Левина Е.А., Ружич В.В. Разномасштабная миграция землетрясений как проявление инициированного энергопотока при волновых деформациях литосферы Земли // Триггерные эффекты в геосистемах: Материалы Всероссийского семинарасовещания. М.: ГЕОС, 2010. С. 71-78].

Liu M., Stein S., Wang H., 2010. A 2000-year record of migrating earthquakes in North China: Implications for earthquake hazards in continental interiors. Geophysical Research Abstracts 12, EGU2010-6785.

Lyubushin A.A., Pisarenko V.F., Ruzhich V.V., Buddo V.Yu., 1998. Identification of periodicity in seismic regime. Vulkanologiya i Seismologiya (1), 62-76 (in Russian) [Любушин А.А., Писаренко В.Ф., Ружич В.В., Буддо В.Ю. Выделение периодичностей в сейсмическом режиме // Вулканология и сейсмология. 1998. № 1. С. 62-76].

Maximov I.V., Vorobiev V.N., Gindin B.V., 1967. On quasi-periodic long-term variations of tide-generating force of the Moon and the Sun. Geomagnetism i Aeronomiya 7 (2), 323 (in Russian) [Максимов И.В., Воробьев В.Н., Гиндин Б.В. 0 квазипериодическом характере долгопериодических изменений приливообразующей силы Луны и Солнца // Геомагнетизм и аэрономия. 1967. Т. 7. № 2. С. 323].

Mogi K., 1968. Migration of seismic activity. Bulletin of Earthquake Research Institute 46, 53-74.

Northern California Earthquake Data Center, On-line Catalogue, 2015. Available from: http://www.ncedc.org (last accessed May 13, 2015).

Novopashina A.V., 2013. The method for identification of seismicity migration in Pribaikalie by GIS. Geoinformatika (1), 33-36 (in Russian) [Новопашина А.B. Методика выявления миграций сейсмической активности Прибайкалья средствами ГИС // Геоинформатика. 2013. № 1. С. 33-36].

Novopashnina A.V., San'kov V.A., 2015. Migration of seismic activity in strike-slip zones: A case study of the boundary between the North American and pacific plates. Russian Journal of Pacific Geology 9 (2), 141-153. http://dx. doi.org/10.1134/S1819714015020050.

Odessky I.A., 1972. Wave Movements of the Earth's Crust. Nedra, Leningrad, 206 p. (in Russian) [Одесский И.А. Волновые движения земной коры. Л.: Недра, 1972. 206 с.].

Orlov V.A., Panov S.V., Parushkin M.D., Fomin Yu.N., 2007. On relationship between seismicity of the Earth and solar activity from results of precision deformographic observations. In: Geodynamics and the State of Stresses of the the Earth Interior. Proceedings of the conference with participation of foreign researchers, 02-05 October 2007. Novosibirsk, p. 77-83 (in Russian) [Орлов В.А., Панов С.В., Парушкин М.Д., Фомин Ю.Н. О связи сейсмичности Земли с солнечной активностью по результатам прецизионных деформографических наблюдений // Геодинамика и напряженное состояние недр Земли: Труды конференции с участием иностранных ученых, 2-5 октября 2007 г. Новосибирск, 2007. С. 77-83].

Ponomareva E.I., Ruzhich V.V., Levina E.A., 2014. On-line middle-term forecast of earthquakes in Pribaikalie and its possibilities. Izvestia, Irkutsk State University. Earth Sciences Series 8, 67-78 (in Russian) [Пономарёва Е.И., Ружич B.B., Левина E.A. Оперативный среднесрочный прогноз землетрясений в Прибайкалье и его возможности // Известия Иркутского государственного университета. Серия «Науки о Земле». 2014. Т. 8. С. 67-78].

Popov V.L., 2013. Mechanics of Contact Interaction and Friction Physics. From Nanotribology to Dynamics of Earthquakes. Fizmatlit, Moscow, 350 p. (in Russian) [Попов В.Л. Механика контактного взаимодействия и физика трения. От нанотрибологии до динамики землетрясений. Москва: Физматлит, 2013. 350 с.].

Revuzhenko A.F., 2013. Tidal Waves and Directional Transfer of the Earth's Masses. Nauka, Novosibirsk, 204 p. (in Russian) [Ревуженко А.Ф. Приливные волны и направленный перенос масс Земли. Новосибирск: Наука, 2013. 204 c.]. 
Ruzhich V.V., 1997. Seismotectonic Destruction of the Earth's Crust in the Baikal Rift Zone. Publishing House of SB RAS, Novosibirsk, 144 p. (in Russian) [Ружич B.B. Сейсмотектоническая деструкция в земной коре Байкальской рифтовой зоны. Новосибирск: Изд-во СО РАН, 1997. 144 с.].

Ruzhich V.V., Khromovskikh V.S., Peryazev V.A., 1989. Analysis of global space-time migration of strong earthquake foci from geotectonic positions. In: Engineering geodynamics and geological medium. Nauka, Novosibirsk, p. 72-80 (in Russian] [Ружич B.B., Хромовских В.С., Перязев В.А. Анализ глобальной пространственно-временной миграции очагов сильных землетрясений с геотектонических позиций // Инженерная геодинамика и геологическая среда. Новосибирск: Наука, 1989. С. 72-80].

Ruzhich V.V., Levina E.A., 2012. Seismomigrational processes as the reflection of internal dynamics in zones of intraplate and interplate faults. In: Recent geodynamics of Central Asia and hazardous natural processes: results of quantitative studies. Proceedings of the All-Russia Meeting and Youth School on Recent Geodynamics (23-29 September 2012, Irkutsk). In 2 volumes. Vol. 2. Institute of the Earth's Crust, SB RAS, Irkutsk, p. 71-74 (in Russian) [Ружич B.B., Левина E.A. Сейсмомиграционные процессы как отражение внутренней динамики в зонах внутриплитных и межплитных разломов // Современная геодинамика Центральной Азии и опасные природные процессы: результаты исследований на количественной основе: Материалы Всероссийского совещания и молодежной школы по современной геодинамике (г. Иркутск, 23-29 сентября 2012 г.). В 2-х т. Иркутск: ИЗК СО РАН, 2012. Т. 2. С. 71-74].

Sherman S.I., 2013. Deformation waves as a trigger mechanism of seismic activity in seismic zones of the continental lithosphere. In: Triggering effects in geosystems. Proceedings of the All-Russia Workshop-Meeting. Institute of Geosphere Dynamics (IDG) RAS, Moscow, p. 46-53 (in Russian) [Шерман С.И. Деформационные волны как тригерный механизм активизации разломов в сейсмических зонах континентальной литосферы // Тригерные эффекты в геосистемах: Материалы II всероссийского семинара-совещания. М.: ИДГ РАН, 2013. C. 46-53].

Sherman S.I., 2014. Seismic Process and the Forecast of Earthquakes: Tectonophysical Conception. Academic Publishing House "Geo", Novosibirsk, 359 p. (in Russian] [Шерман С.И. Сейсмический процесс и прогноз землетрясений: тектонофизическая концепция. Новосибирск: Академическое издательство «Гео», 2014. 359 с.].

Shestopalov I.P., Kharin E.P., 2004. On relationship between the Earth seismicity and solar and geomagnetic activity. In: Solar-Earth Relationships and Electomagnetic Precursors of Earthquakes. IKIR FEB RAS, PetropavlovskKamchatsky, p. 64-76 (in Russian) [Шестопалов И.П., Харин Е.П. О связи сейсмичности Земли с солнечной и геомагнитной активностью // Солнечно-земные связи и электромагнитные предвестники землетрясений. Петропавловск-Камчатский: ИКИР ДВО РАН, 2004. С. 64-76].

Sidorenkov N.S., 2004. Instability of the Earth rotation. Vestnik, Russian Academy of Sciences 74 (8), 701-715 (in Russian) [Сидоренков Н.C. Нестабильность вращения Земли // Вестник Российской академии наук. 2004. T. 74. № 8. C. 701-715].

Sobolev G.A., Shestopalov I.P., Kharin E.P., 1998. Implications of solar flares for the seismic activity of the Earth. Izvestiya, Physics of the Solid Earth 34 (7), 603-607.

StatSoft, On-line Statistics Guidebook, 2015. Available from: http://www.statsoft.ru/home/textbook/modules/ stcluan.html (last accessed May13, 2015).

Stovas M.V., 1963. On the loaded state of the crustal layer in the zone between 30 and $40^{\circ}$. In: Problems of Planetary Geology. Gosgeoltekhizdat, Moscow, p. 275-284 (in Russian] [Стовас М.B. О нагруженном состоянии корового слоя в зоне между 30 и 40// Проблемы планетарной геологии. М.: Госгеолтехиздат, 1963. С. 275-284].

Tsaregradsky V.A., 1963. On the issue of deformation of the Earth's crust. In: Problems of planetary geology. Gosgeoltekhizdat, Moscow, p. 149-221 (in Russian) [Цареградский В.А. К вопросу о деформациях земной коры // Проблемы планетарной геологии. М.: Госгеолтехиздат, 1963. С. 149-221].

Tyapkin K.F., 2012. Variations of the position of the rotation axis in the Earth body: cause, mechanism and use for explanation of global tectonic processes in the Earth's crust. Geophysical Journal 34 (6), 91-100 (in Russian) [Тяпкин К.Ф. Изменение положения оси вращения в теле Земли: причина, механизм и использование для объяснения глобальных тектонических процессов в земной коре // Геофизический журнал. 2012. Т. 34. № 6. C. 91-100].

Utkin V.I., Yurkov A.K., Tsurko I.A., 2012. Variations of irregularity of earth rotation as triggering factor of seismicity. Geologiya i Geofizika Yuga Rossii (1), 3-13 (in Russian) [Уткин В.И., Юрков А.К., Цурко И.А. Вариации неравномерного вращения Земли как триггирующий фактор сейсмичности планеты // Геология и геофизика юга России. 2012. № 1. С. 3-13].

Vikulin A.V., 2003. Physics of Wave Seismic Process. KOMSP GS RAS, KSTU, Petropavlovsk-Kamchatsky, 152 p. (in Russian) [Викулин А.В. Физика волнового сейсмического процесса. Петропавловск-Камчатский: КОМСП ГС РАН, КГПУ, 2003. 152 с.].

Vikulin A.V., Akmanova D.R., Vikulina S.A., Dolgaya A.A., 2012. Migration of seismic and volcanic activity as display of wave geodynamic process. Geodynamics \& Tectonophysics 3 (1), 1-18. http://dx.doi.org/10.5800/GT-2012-3-10058.

Vikulin A.V., Bykov V.G., Luneva M.N., 2000. Nonlinear deformation waves in a rotational model of a seismic process. Computational Technologies 5 (1), 31-39 (in Russian) [Викулин А.В., Быков В.Г., Лунева М.Н. Нелинейные волны деформации в ротационной модели сейсмического процесса // Вычислительные технологии. 2000. Т. 5. № 1. С. 31-39]. 


\section{E.A. Levina, V.V. Ruzhich: The seismicity migration study...}

Vikulin A.V., Ivanchin A.G., 2015. Rotational movements of geomedium - an alternative to plate tectonics. In: Tectonics and geodynamics of continental and oceanic lithosphere: general and regional aspects. Proceedings of the XLVII Tectonic Meeting. Vol. 1. GEOS, Moscow, p. 62-67 (in Russian) [Викулин А.В., Иванчин А.Г. Вращательные движения геосреды - альтернатива тектонике плит // Тектоника и геодинамика континентальной и океанической литосферы: общие и региональные аспекты: Материалы XLVII Тектонического совещания. М.: ГЕОС, 2015. T. 1. С. 62-67].

Vorobiev V.N., 1971. Some consequences of analysis of total potential of long-term part of tide-generation force. Geomagnetism i Aeronomiya 11 (1), 189 (in Russian) [Воробьев В.Н. Некоторые следствия анализа суммарного потенциала долгопериодической части приливообразующей силы // Геомагнетизм и аэрономия. 1971. T. 11. № 1. C. 189].

Zagoruiko N.G., 1999. Applied Methods of Data and Knowledge Analysis. Publishing House of Institute of Mathematics, SB RAS, Novosibirsk, 270 p. (in Russian) [Загоруйко Н.Г. Прикладные методы анализа данных и знаний. Новосибирск: Изд-во Ин-та математики СО РАН, 1999. 270 с.].

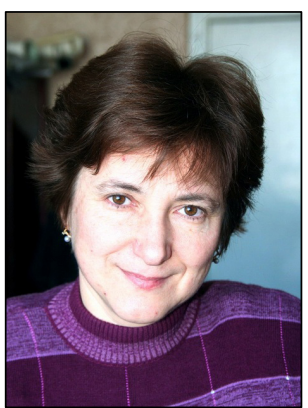

Levina, Elena A., Candidate of Geology and Mineralogy

Institute of the Earth's Crust SB RAS

128 Lermontov street, Irkutsk 664033, Russia

e-mail: levina@crust.irk.ru

Левина Елена Алексеевна, канд. геол.-мин. наук, н.с.

Институт земной коры СО РАН

664033, Иркутск, ул. Лермонтова, 128, Россия

e-mail: levina@crust.irk.ru

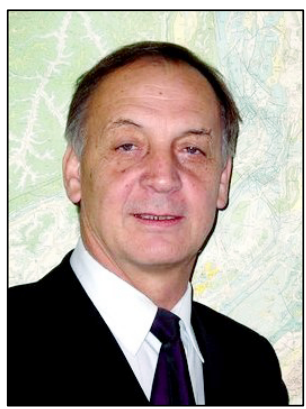

Ruzhich, Valery V., Doctor of Geology and Mineralogy, Chief Researcher

Institute of the Earth's Crust SB RAS

128 Lermontov street, Irkutsk 664033, Russia

Tel. +7(3952)422776; e-mail: ruzhich@crust.irk.ru

Ружич Валерий Васильевич, докт. геол.-мин. наук, г.н.с.

Институт земной коры СО РАН

664033, Иркутск, ул. Лермонтова, 128, Россия

Тел. (3952)422776; e-mail: ruzhich@crust.irk.ru 